Mahrani, et al/Jurnal Ekonomi Syariah Teori dan Terapan Vol. 6 No. 2 Fevbruari 2019: 254-269; PENERAPAN PRINSIP AKAD MUDHARABAH PADA INVESTASI SYARIAH HEWAN TERNAK PT IJADGRUP RAHMAT SEMESTA

\title{
PENERAPAN PRINSIP AKAD MUDHARABAH PADA INVESTASI SYARIAH HEWAN TERNAK PT IJADGRUP RAHMAT SEMESTA
}

\author{
Mohammad Razan Mahrani \\ Departemen Ekonomi Syariah-Fakultas Ekonomi dan Bisnis-Universitas Airlangga \\ Email: razanmahrani@gmail.com
}

Muhammad Nafik Hadi Ryandono

Departemen Ekonomi Syariah-Fakultas Ekonomi dan Bisnis-Universitas Airlangga

Email: muhammadnafik@feb.unair.ac.id

\begin{abstract}
:
This study aims to determine the application of sharia principles contained in the investment of livestock implemented by PT ljadgrup Rahmat Semesta in his company called ljadfarm. The approach used is a qualitative approach with a case study strategy. Data collection is conducted by interviewing the related parties. the analytical technique that is used is source triangulation technique, pattern matching technique and descriptive qualitative analysis technique. The results of this study are the sharia principles applied by ljadfarm in the investment of livestock are in accordance with sharia principles established by DSN MUI.
\end{abstract}

Keywords: Principles of Sharia Investment, Mudharabah, Sharia Husbandry, Fatwa DSN MUI

I. Pendahuluan

Islam memiliki konsep tentang maqashid syariah yaitu tujuan dari diciptakannya aturan- aturan dalam Islam.Aturan-aturan tersebutlah yang dimaksudkan untuk memberikan jaminan keselamatan pada umat manusia sepanjang hidupnya baik lahir maupun batin. Keselamatan yang dimaksud dalam maqashid syariah antara lain merupakan keselamatan dalam memeluk agama, keselamatan diri yang termasuk jiwa serta raga, keselamatan akal, keselamatan keturunan dan juga keselamatan harta benda. Penerapan konsep maqashid syariah ini menjadi bagian dari kebutuhan dharuriyyat karena apabila kelima hal diatas tidak terjamin keselamatannya maka keselamatan kehidupan manusia dapat terancam (Antonio, 2001:7).
Indonesia juga merupakan salah satu negara yang memiliki wilayah yang sangat luas serta jumlah penduduk yang banyak sekali memadati setiap wilayah tanah air.Bahkan, Indonesia masuk dalam 5 besar negara dengan jumlah penduduk terbanyak di dunia. Selain sumber daya manusia yang melimpah, Indonesia juga dikenal sebgai negara yang kaya akan sumber daya alamnya. Berada pada garis khatulistiwa membuat Indonesia sebagai negara yang strategis dan memiliki prospek bisnis yang baik.Hutan, gunung sawah dan lautan merupakan suatu kenikmatan yang bisa dirasakan dan dimanfaatkan oleh masyarakat Indonesia untuk berbagai hal mulai dari untuk memenuhi kebutuhan individu hinga kebutuhan bisnis.

Peternakan merupakan salah satu bidang banyak digeluti oleh masyarakat

1) Jurnal ini merupakan bagian dari skripsi Mohammad Razan Mahrani, NIM: 041411433002 , yang diuji pada tanggal 23 Juli 2018 
Mahrani, et al/Jurnal Ekonomi Syariah Teori dan Terapan Vol. 6 No. 2 Fevbruari 2019: 254-269; PENERAPAN PRINSIP AKAD MUDHARABAH PADA INVESTASI SYARIAH HEWAN TERNAK PT IJADGRUP RAHMAT SEMESTA

di Indonesia. Mulai dari masyarakat pedesaan yang masih memiliki lahan yang luas serta hijauan yang banyak hingga perkotaan yang lahannya seadanya selalu ada yang menggeluti bidang bisnis ini karena potensi dalam bisnis ternak cukup tinggi dan dapat menghasilkan pendapatan yang tinggi. Hal tersebut didukung juga dengan kebutuhan masyarakat Indonesia akan daging sapi maupun ayam untuk memenuhi kebutuhan pangan sehari-hari.

Dalam Islam, sebenarnya kegiatan beternak merupakan salah satu hal yang dilakukan oleh para nabi utusan Allah SWT untuk memenuhi kebutuhan mereka agar tetap bisa menjalani kehidupan di dunia. Rasulullah Muhammad SAW juga merupakan seorang peternak. Beliau menggembala domba milik keluarganya sendiri dan juga menggembala domba milik orang lain dengan upah/gaji sebesar satu qirath.

Plt Direktur Kesehatan Masyarakat Veteriner, Dirjen Peternakan, dan Kesehatan Hewan (Dirjen PKH) Kementan, Agung Suganda, mengatakan angka prognosa kebutuhan daging sapi sepanjang tahun 2017 mencapai 604.966 ton berdasarkan asumsi rata-rata konsumsi nasional sebesar 2,31 kg/kapita/tahun (BPS, 2016). Sementara itu, target produksi daging dalam negeri tahun 2017 sebesar 354.770 ton, sehingga terdapat kekurangan sebesar 250.196 ton.

Dihimpun dari outlook daging sapi yang dipublikasikan oleh Kementrian Pertanian pada tahun 2016, berdasarkan hasil proyeksi besarnya konsumsi daging sapi pada tahun 2015 sebesar 2,40 kg/kapita/tahun, tahun 2016 diproyeksikan sebesar $2,41 \mathrm{~kg} / \mathrm{kapita} / \mathrm{tahun}$ dan tahun 2017 di proyeksikan sebesar 2,43 kg/kapita/tahun sementara tahun 2018 2020 mengalami penurunan dari 0,41 hingga 0,88 atau selama tahun 2015-2020 mengalami pertumbuhan rata-rata sebesar $0,13 \%$.

Dalam menghitung proyeksi konsumsi nasional dibutuhkan informasiinformasi sebagai berikut:

1. Jumlah penduduk Indonesia pada tahun dasar,

2. Laju pertumbuhan jumlah penduduk Indonesia per tahun,

3. Tingkat konsumsi komoditas yang dianalisis per kapita per tahun.

Untuk memenuhi informasi tersebut dilakukan langkah atau diambil asumsi sebagai berikut. Pertama, data jumlah penduduk Indonesia yang digunakan data proyeksi jumlah penduduk Indonesia 2015 s.d 2035 yang dipublikasikan oleh BPS.

Hasil proyeksi konsumsi nasional daging sapi disajikan pada Konsumsi total daging sapi Indonesia diproyeksikan akan naik selama periode 2014 - 2020 dengan laju pertumbuhan rata-rata sebesar 1,35\% pertahun. Secara absolut konsumsi daging sapi diproyeksikan mengalami kenaikan dari 595,11 ribu ton pada tahun 2014 menjadi 644,73 ribu ton pada tahun 2020 . Data proyeksi permintaan daging sapi di Indonesia pada tahun 2014-2020 sendiri dapat dilihat pada tabel 1 
Mahrani, et al/Jurnal Ekonomi Syariah Teori dan Terapan Vol. 6 No. 2 Fevbruari 2019: 254-269; PENERAPAN PRINSIP AKAD MUDHARABAH PADA INVESTASI SYARIAH HEWAN TERNAK PT IJADGRUP RAHMAT SEMESTA

Tabel 1.

Hasil Proyeksi Permintaan Daging Sapi di Indonesia pada tahun 2014-2020

\begin{tabular}{|c|c|c|}
\hline Tahun & $\begin{array}{c}\text { Konsumsi } \\
\text { Nasional Daging } \\
\text { Sapi ( 000 Ton ) }\end{array}$ & Pertumbuhan (\%) \\
\hline 2014 & 595,11 & 3,02 \\
\hline $\left.2015^{*}\right)$ & 613,11 & 1,69 \\
\hline $\left.2016^{*}\right)$ & 623,43 & 2,07 \\
\hline $2017^{*}$ ) & 636,39 & 0,77 \\
\hline $2018^{*}$ ) & 641,33 & 0,22 \\
\hline $\left.2019^{*}\right)$ & 642,76 & 0,31 \\
\hline $\left.2020^{*}\right)$ & 644,73 & 1,35 \\
\hline \multicolumn{2}{|c|}{ Rata-rata Pertumbuhan } \\
\hline
\end{tabular}

Keterangan: *) Angka Proyeksi Pusdatin

Sumber: Outlook Daging Sapi Kementrian

Pertanian tahun 2016

Berdasarkan data tabel yang didapat dari outlook daging sapi 2016 yang diterbitkan oleh Kementrian Pertanian dapat dilihat bahwa produksi daging sapi dalam skala nasional untuk tahun 2014 - 2020 diproyeksikan akan cenderung naik dengan rata-rata laju pertumbuhan per tahunnya mencapai 1,93. Senada dengan produksi, demikian pula untuk konsumsi daging sapi nasional dari tahun 2014 - 2020 di prediksi akan naik dengan rata-rata pertumbuhan dari tahun 2014 - 2020 naik hingga mencapai $1,35 \%$. Kenaikan prediksi produksi daging sapi hingga tahun 2020 dengan pertumbuhan lebih besar dari pertumbuhan konsumsi daging sapi, namun belum dapat memenuhi kebutuhan konsumsi daging sapi nasional, hal ini membuat terjadinya defisit daging sapi hingga tahun 2020.

Defisit daging sapi yang tertinggi terjadi pada tahun 2017 sebesar 211,42 ribu ton dan yang terendah terjadi pada tahun 2020 sebesar 198,35 ribu ton, rata- rata defisit daging sapi dari tahun 2014 2020 sebesar 204,50 ribu ton atau pertumbuhan defisit hingga $0.17 \%$. Melihat dari defisit daging sapi hingga tahun 2020 terus naik, di mungkinkan akan menambah impor daging sapi khusunya dari Australia untuk memenuhi konsumsi daging sapi. Namun sebagai catatan bahwa penurunan defisit daging sapi hanya dihitung berdasarkan konsumsi rumah tangga, sementara kebutuhan daging sapi di luar rumah tangga yang di perkirakan cukup besar belum terhitung.

Dalam Islam, kegiatan berdagang sangat dianjurkan pada kita untuk memenuhi kebutuhan hidup. Bahkan,terdapat suatu hadits yang menyatakan sembilan dari sepuluh pintu rezeki adalah dengan berdagang. Walaupun hadits tersebut dinyatakan sebagai hadits yang lemah, namun dapat memotivasi para pengusaha untuk tetap berdagang.Lingkungan Rasulullah SAW juga tidak asing dengan berdagang.Rasulullah SAW sendiri adalah seorang pedagang, istri kesayangannya juga seorang pedagang serta sahabatsahabatnya berdagang juga.

Selain turun langsung untuk melakukan kegiatan ternak mulai dari perawatan hingga penjualan, ada juga yang membuka jalur investasi saja sehingga pihak yang berinvestasi tidak turun langsung dalam memelihara ternak dan apabila hewan ternak tersebut terjual maka yang berinvestasi akan mendapatkan bonus atas penjualan tersebut. Dalam Islam juga telah dikenal 
Mahrani, et al/Jurnal Ekonomi Syariah Teori dan Terapan Vol. 6 No. 2 Fevbruari 2019: 254-269; PENERAPAN PRINSIP AKAD MUDHARABAH PADA INVESTASI SYARIAH HEWAN TERNAK PT IJADGRUP RAHMAT SEMESTA

istilah investasi sejak zaman dahulu.Investasi yang berarti menunda pemanfaatan harta yang kita miliki pada saat ini, atau berarti menyimpan, mengelola dan mengembangkannya merupakan hal yang dianjurkan dalam AlQur'an seperti yang dijelaskan dalam AlQur'an Surat Yusuf 12: ayat 46-49.

Ayat tersebut mengajarkan kepada kita untuk tidak mengkonsumsi semua kekayaan yang kita miliki pada saat kita telah mendapatkannya, tetapi sebagian kekayaan yang kita dapatkan hendaknya kita tangguhkan pemanfaatannya untuk keperluan yang lebih penting. Dengan bahasa lain, ayat tersebut mengajarkan kepada kita untuk mengelola dan mengembangkan kekayaan demi untuk mempersiapkan masa depan.

Di Indonesia, investasi bukanlah suatu hal yang baru dan tidak menarik. Dengan potensi Indonesia yang begitu banyak dan kaya akan sumber daya alam membuat para investor baik dalam negeri maupun luar negeri untuk menginvestasikan dana mereka di Indonesia dalam berbagai sektor.

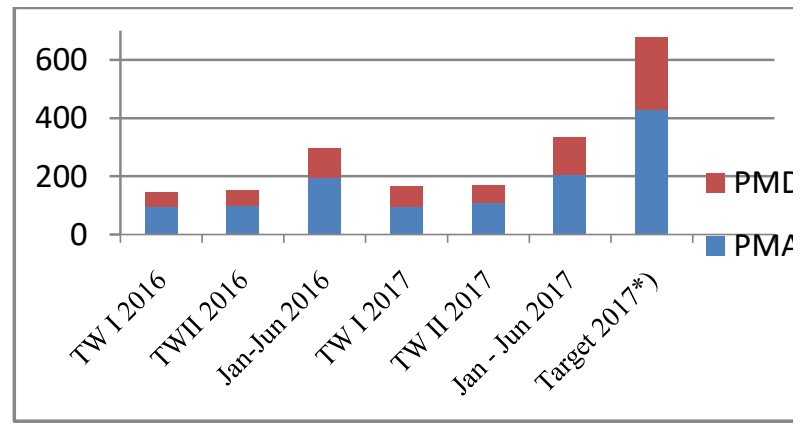

Sumber : www.bkpm.go.id

Gambar 1. Perkembangan Realisasi Penanaman Modal di Indonesia Triwulan II tahun 2017
Berdasarkan data yang didapat dari situs resmi badan koordinasi penanaman modal Indonesia, perkembangan realisasi penanaman modal pada Triwulan ke II tahun 2017 pada penanaman modal asing tercapai realisasi sebesar $48,2 \%$ dari target pada tahun 2017 yaitu sebesar 206,9 triliun dari 429,0 triliun rupiah. Sedangkan untuk penanaman modal dalam negeri, realisasi nya tercapai sebesar $52 \%$ dari target pada tahun 2017 yaitu sebesar 129,8 triliun dari 249,8 triliun rupiah. Hal tersebut menyatakan bahwa tingkat investasi di Indonesia cukup tinggi baik dari pihak asing maupun dalam negeri.

Dewasa ini, terdapat banyak sekali koperasi atau badan usaha non syariah yang membuka kesempatan bagi para investor untuk berinvestasi di bidang penggemukan sapi potong maupun untuk kegiatan idul adha. Yang menarik untuk dibahas ialah dimana koperasi atau badan usaha yang non syariah menawarkan kerjasama tersebut dengan prinsip syariah dengan akad mudharabah (bagi hasil).

Di Surabaya Jawa Timur terdapat perusahaan terbuka yang bernama PT ljadgrup Rahmat Semesta yang membuka jalur investasi yang berbasis syariah. Perusahaan tersebut meyakinkan bahwa investasi yang mereka tawarkan tidak terkandung riba sama sekali di dalamnya dan juga menggunakan akad mudharabah (investor berkontribusi pada modal, perusahaan berkontribusi pada tenaga dan pengelolaan hewan ternak. 
Mahrani, et al/Jurnal Ekonomi Syariah Teori dan Terapan Vol. 6 No. 2 Fevbruari 2019: 254-269; PENERAPAN PRINSIP AKAD MUDHARABAH PADA INVESTASI SYARIAH HEWAN TERNAK PT IJADGRUP RAHMAT SEMESTA

Sehingga sudah banyak investor yang mencoba untuk berinvestasi syariah pada perusahaan tersebut.

Tentu saja hal tersebut menarik sekali untuk diteliti karena fenomena saat ini banyak sekali peternak dan perusahaan yang membuka kerjasama dalam bentuk investasi dengan akad mudharabah (bagi hasil) padahal mereka masih belum memiliki legalitas yang syariah.Tentu saja, dengan dibuka nya investasi syariah yang ber akad mudharabah tersebut haruslah sesuai dengan prinsip syariah serta fatwa DSN MUI agar tidak menyalahi aturan. Karena hal tersebut, menarik sekali Investasi Mudharabah yang ditawarkan oleh PT ljadgrup Rahmat Semesta untuk diteliti dan di analisa penerapan prinsip syariahnya.

\section{Rumusan Masalah}

Berdasarkan uraian latar belakang diatas, maka rumusan masalah dalam penelitian ini adalah Bagaimana Penerapan Akad mudharabah dalam Investasi Hewan Ternak pada PT ljadgrup Rahmat Semesta?

\section{Tujuan Penelitian}

Sesuai dengan rumusan masalah diatas, maka tujuan dari penelitian ini adalah untuk mengetahui dan menjelaskan bagaimana Penerapan Prinsip Syariah Akad mudharabah pada PT ljadgrup Rahmat Semesta dan menjelaskan penerapan prinsip mudharabah dalam bidang peternakan.

\section{LANDASAN TEORI}

\section{Kaidah Islam di Bidang Peternakan}

Dalam Al-Qur'an, terdapat beberapa ayat yang menjelaskan tentang peternakan dan fungsi dari hewan ternak untuk manusia. Yang pertama terdapat pada surat Al-Mukmin (40) : 79-80, Al-Mukminun (23) 21-22, dan An-Nahl (16) 5-8 .

QS Al-Mukmin (40): 79-80. Allah SWT berfirman:

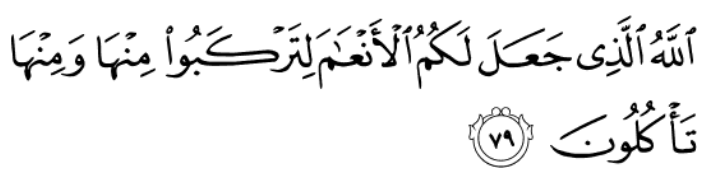

Al-Lahu Al-Ladhī Ja ala Lakumu Al-'An `ām Litarkabū Minhā Wa Minhā Ta'kulūna Artinya:"Allahlah yang menjadikan binatang ternak untuk kamu, sebagiannya untuk kamu kendarai dan sebagiannya untuk kamu makan".

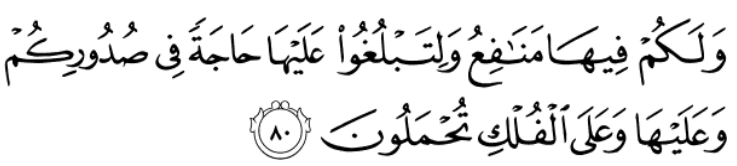

Wa Lakum Fihā Manāfi U Wa Litablughū ‘Alayhā Hājatan Fı Şudūrikum Wa `Alayhā Wa `Alá Al-Fulki Tuĥmalūna

Artinya:" Dan (ada lagi) manfaat-manfaat yang lain pada binatang ternak itu untuk kamu dan supaya kamu mencapai suatu keperluan yang tersimpan dalam hati dengan mengendarainya. Dan kamu dapat diangkut dengan mengendarai binatang-binatang itu dan dengan mengendarai bahtera".

Berdasarkan tafsir Ibnu Katsir, potongan surat Al-Mukmin ayat 79-80 tersebut memiliki penafsiran bahwa Allah SWT berfirman, menyebutkan anugerah 
Mahrani, et al/Jurnal Ekonomi Syariah Teori dan Terapan Vol. 6 No. 2 Fevbruari 2019: 254-269; PENERAPAN PRINSIP AKAD MUDHARABAH PADA INVESTASI SYARIAH HEWAN TERNAK PT IJADGRUP RAHMAT SEMESTA

yang telah Dia berikan kepada hambahamba-Nya bahwa Dia telah menciptakan bagi mereka binatang ternak, seperti unta, sapi, dan kambing; yang sebagiannya ada yang dapat dijadikan sebagai kendaraan mereka, dan sebagian yang lainnya untuk mereka makan. Unta dikendarai, dimakan, dapat diperah air susunya, dan dapat dijadikan sebagai pembawa barang-barang berat dalam perjalanan atau sebagai tunggangan menuju ke negeri yang jauh dan menempuh kawasan yang luas.Sapi dimakan dagingnya dan diminum susunya serta dapat dijadikan sebagai sarana untuk membajak tanah.Sedangkan ternak kambing dagingnya dimakan, susunya diminum, dan bulunya dapat dicukur, lalu dijadikan kain dan pakaian serta kebutuhan perabotan lainnya.

QS An-Nahl(16) 5-8. Allah SWT berfirman :

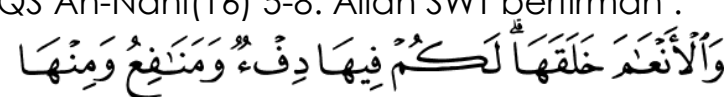

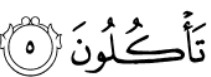
Wa Al-'An 'āma Khalaqahā Lo Lakum Fihā Dif'un Wa Manāfi u Wa Minhā Ta'kulūna

Artinya :"Dan Dia telah menciptakan binatang ternak untuk kamu; padanya ada (bulu) yang menghangatkan dan berbagai-bagai manfaat, dan sebahagiannya kamu makan".

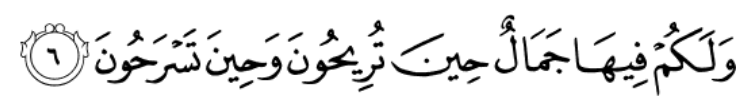

Wa Lakum Fihā Jamālun Hîna Turîhūna Wa Hīina Tasraĥūna

Artinya: "Dan kamu memperoleh pandangan yang indah padanya, ketika kamu membawanya kembali ke kandang dan ketika kamu melepaskannya ke tempat penggembalaan"

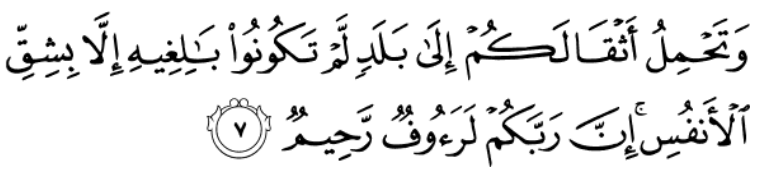

Wa Taĥmilu 'Athqālakum 'llá Baladin Lam Takūnū Bālighīhi 'Illā Bishiqqi Al-'Anfusi ¿̌ 'Inna Rabbakum Lara'ūfun Raĥ̄mun

Artinya: "Dan ia memikul beban-bebanmu ke suatu negeri yang kamu tidak sanggup sampai kepadanya, melainkan dengan kesukaran-kesukaran

lyang memayahkan) diri. Sesungguhnya Tuhanmu benar-benar Maha Pengasih lagi Maha Penyayang,

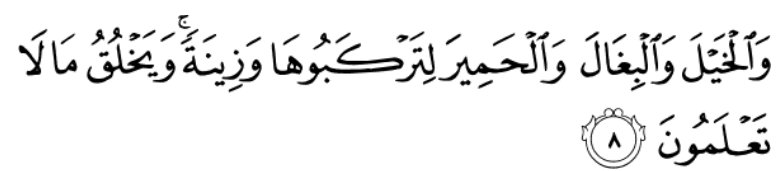

Wa Al-Khayla Wa Al-Bighāla Wa Al-Ĥamira Litarkabūhā Wa Zinatan ¿̇ Wa Yakhluqu Mā Lā Ta`lamūna

Artinya: "dan (Dia telah menciptakan) kuda, bagal dan keledai, agar kamu menungganginya dan (menjadikannya) perhiasan. Dan Allah menciptakan apa yang kamu tidak mengetahuinya."

Berdasarkan tafsir Ibnu Katsir, potongan ayat tersebut memiliki artian bahwa Allah SWT memberi anugerah kepada hamba-Nya dengan apa yang diciptakan untuk mereka, berupa binatang-binatang ternak, yaitu unta, sapi dan domba. Sebagaimana Allah telah merincinya dalam surah al-An'am, hingga berjumlah delapan pasang.Dan Allah jadikan pula untuk mereka kemashlahatan dan kemanfaatan yang 
Mahrani, et al/Jurnal Ekonomi Syariah Teori dan Terapan Vol. 6 No. 2 Fevbruari 2019: 254-269; PENERAPAN PRINSIP AKAD MUDHARABAH PADA INVESTASI SYARIAH HEWAN TERNAK PT IJADGRUP RAHMAT SEMESTA

terdapat pada binatang-binatang itu, dari bulu domba, bulu unta, dan bulu kambing. Mereka dapat menggunakannya sebagai pakaian dan permadani.Merekapun minum susunya dan makan anak-anak binatang tersebut.

Dari berbagai ayat yang telah menjelaskan tentang peternakan, dapat diambil sebuah garis besar bahwa Allah SWT menciptakan hewan ternak yang memiliki fungsi dan manfaat yang sangat banyak sekali untuk manusia. Manfaatmanfaat tersebut antara lain adalah sebagai alat transportasi dalam bepergian, lalu bulu dan kulitnya bisa dimanfaatkan sebagai baju, sepatu, dan alat-alat lainnya. Dan yang paling bermanfaat adalah hewan ternak dapat dikonsumsi oleh masyarakat sehingga dapat memenuhi kebutuhan pangan masyarakat.Begitu banyak sekali manfaat yang bisa didapat dari hewan ternak. Hingga terdapat suatu pernyataan dari filsuf arab yang dikutip dari Campbell dan Lasley yaitu "Negara yang kaya dengan ternak tidak akan pernah miskin, dan negara yang miskin dengan ternak tidak akan pernah kaya."

\section{Investasi dalam perspektif Islam}

Investasi dalam bahasa Arab disebut dengan kata (الاستثمار) berasal darifi'il ثمر yang bermakna menginvestasikan atau mengembangkan. Para ulama membuat suatu kesepakatan bahwa sistem penanaman modal ini diperbolehkan dalam Islam.Dasar hukum dari sistem ini adalah ijma' ulama yang memperbolehkannya. Diriwayatkan juga dari al-Alla bin Abdurahman, bahwa Utsman bin Affan memberinya uang sebagai modal usaha dan keuntungannya dibagi menjadi dua.

Menurut para ulama investasi bisa dikatakan sah apabila memenuhi 3 kriteria syarat berikut ini:

1. Pelaku (investor)

2. Akad perjanjian

3. Obyek transaksi

\section{Akad Musyarakah}

Akad Musyarakah merupakan akad kerja sama yang terjadi antara dua pihak atau lebih untuk melakukan suatu usaha tertentu dimana setiap pihak harus memberikan konstribusi dana dengan kesepakatan bahwa keuntungan dan resiko dalam usaha akan ditanggung bersama sesuai dengan kesepakatan yang disepakati diawal. Akad musyarakah sendiri termasuk kedalam akad tijarah.Berbagai ulama juga memiliki beberapa definisi yang berbeda-beda tentang akad musyarakah itu sendiri.

$$
\text { Menurut Hanafiah, akad }
$$
musyarakah atau syirkah adalah suatu ungkapan tentang akad atau perjanjian yang dilakukan antara dua orang yang berserikat di dalam modal maupun keuntungan.Menurut Malikiyah, musyarakah memiliki definisi sebagai suatu bentuk persetujuan untuk melakukan tasarruf bagi kedua pihak beserta diri mereka, yakni setiap orang yang berserikat memberikan persetujuan kepada teman serikatnya untuk melakukan tasarruf terhadap harta 
Mahrani, et al/Jurnal Ekonomi Syariah Teori dan Terapan Vol. 6 No. 2 Fevbruari 2019: 254-269; PENERAPAN PRINSIP AKAD MUDHARABAH PADA INVESTASI SYARIAH HEWAN TERNAK PT IJADGRUP RAHMAT SEMESTA

keduanya di samping masih tetapnya hak tasarruf bagi masing-masing peserta.

Sedangakan menurut ulama Syafi'iyah, syirkah menururt syara' adalah suatu ungkapan tentang penetapan suatu hak atas suatu barang bagi dua orang atau lebih secara bersamasama.Dan menurut ulama Hanabilah, definisi dari syirkah sendiri adalah berkumpul atau bersama-sama dalam kepemilikan atas hak atau tasarruf.

\section{Akad Mudharabah}

Menurut Ulama Fiqh,kerjasama "mudharabah" sering juga disebut dengan "Qiradh". Dalam Fiqh Sunnah juga disebutkan bahwa mudharabah bisa dinamakan dengan qiradh yang memiliki arti memotong.Karena pemilik modal memotong sebagian hartanya untuk diperdagangkan dengan memperoleh sebagian keuntungan.

Secara istilah, mudharabah merupakan akad kerjasama usaha antara dua pihak dimana pihak pertama (pemilik dana) menyediakan seluruh dana, sedangkan pihak kedua (pengelola dana) bertindak selaku pengelola, dan keuntungan usaha dibagi diantara mereka sesuai kesepakatan sedangkan kerugian finansialnya hanya ditanggug oleh pengelola dana.

Akad mudharabah yang merupakan salah satu bentuk kerjasama antar individu dengan maksut dan tujuan untuk mendapatkan keuntungan dan kemashlahatan bagi yang menjalankan serta barokah dari Allah SWT tentunya memiliki dasar hukum yang berdasar dari Al-Quran dan hadits.

Dalam Al-Quran terdapat beberapa ayat yang menekankan untuk umat manusia agar saling menolong dan menggunakan hartanya untuk kemashlahatan bersama seperti yang tertera pada surat An-Nisa ayat 29 dan juga Al Baqarah ayat 245

.Allah SWT berfirman pada An-Nisa ayat 29 sebagai berikut:

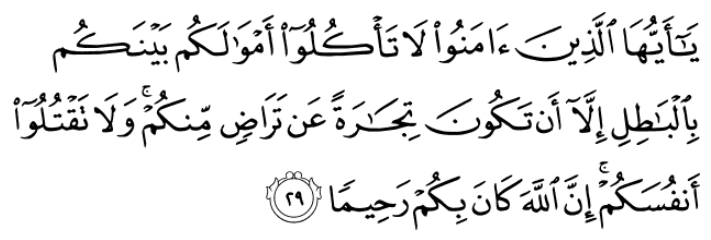

Yā 'Ayyuhā Al-Ladhina 'Āmanū Lā Ta'kulū'Amwālakum Baynakum Bil-Bāṭili 'Illā 'An Takūna Tijāratan `An Tarāđin Minkum है Wa Lā Taqtulū'Anfusakum '̌ 'Inna Allāha Kāna Bikum Rahīmāan

Artinya: "Hai orang-orang yang beriman, janganlah kamu saling memakan harta sesamamu dengan jalan yang batil, kecuali dengan jalan perniagaan yang berlaku dengan suka sama-suka di antara kamu. Dan janganlah kamu membunuh dirimu; sesungguhnya Allah adalah Maha Penyayang kepadamu."

Pada ayat tersebut terdapat lafaz tijaratan dapat pula dibaca tijaratun. Lafaz tersebut seakan-akan dapat dikatakan, "Janganlah kalian menjalankan usaha yang menyebabkan perbuatan yang diharamkan, tetapi berniagalah menurut peraturan yang diakui oleh syariat, yaitu perniagaan yang dilakukan suka sama suka di antara pihak pembeli dan pihak penjual; dan carilah 
Mahrani, et al/Jurnal Ekonomi Syariah Teori dan Terapan Vol. 6 No. 2 Fevbruari 2019: 254-269; PENERAPAN PRINSIP AKAD MUDHARABAH PADA INVESTASI SYARIAH HEWAN TERNAK PT IJADGRUP RAHMAT SEMESTA

keuntungan dengan cara yang diakui oleh syariat." Jadi, pada intinya setiap perniagaan harus mengutamakan prinsip suka sama suka antara pembeli dan penjual.

Pada surat Al Baqarah ayat 245, Allah SWT berfirman sebagai berikut :

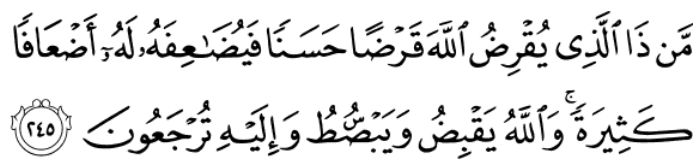
man dzaa ladzii yuqridhu laaha gardhan hasanan fayudaalifahu lahu adh'áafan katsiiratan walaahu yaqbidhu wayabsuthu wa-ilayhi turja'uun

Artinya :"Siapakah yang mau memberi pinjaman kepada Allah, pinjaman yang baik (menafkahkan hartanya di jalan Allah), maka Allah akan meperlipat gandakan pembayaran kepadanya dengan lipat ganda yang banyak. Dan Allah menyempitkan dan melapangkan (rezeki) dan kepada-Nya-lah kamu dikembalikan."

Berdasarkan tafsir jalalayn, ayat tersebut dapat ditafsirkan yakni siapakah yang bersedia memberi pinjaman kepada Allah yaitu dengan menafkahkan hartanya di jalan Allah (yakni pinjaman yang baik) dengan ikhlas kepada-Nya semata, (maka Allah akan menggandakan) pembayarannya; menurut satu qiraat dengan tasydid hingga berbunyi 'fayudha'ifahu' (hingga berlipat-lipat) mulai dari sepuluh sampai pada tujuh ratus lebih sebagaimana yang akan kita temui nanti (Dan Allah menyempitkan) atau menahan rezeki orang yang kehendaki-Nya sebagai ujian (dan melapangkannya) terhadap orang yang dikehendaki-Nya, juga sebagai cobaan (dan kepada-Nya kamu dikembalikan) di akhirat dengan jalan akan dibangkitkan dari matimu dan akan dibalas segala amal perbuatanmu.

Menurut Karim (2004:182) faktorfaktor yang harus ada (rukun) dalam akad mudharabah adalah:

1) Pelaku (pemilik modal maupun pelaksana usaha)

2) Obyek mudharabah (modal dan kerja).

3) Persetujuan kedua belah pihak (ijab-qabul).

4) Nisbah keuntungan.

Akad mudharabah bisa dikatakan berakhir antara mudharib dan shahibul maal apabila :

- Salah satu pihak memutuskan untuk mengundurkan diri dari perjanjian, baik dengan alasan diterima maupun tidak diterima. Karena akad ini haruslah terjadi dengan kesediaan kedua belah pihak tanpa ada paksaan.

- Dalam hal mudharabah tersebut, dibatasi waktunya atau diberikan waktu jelasnya

- Jika salah satu pihak telah meninggal dunia atau mengalami kehilangan akal sehingga dianggap sebagai hilangnya kesepakatan.

- Pengelola yang diamanahkan sebagai pengelola usaha tidak dapat menjalankan amanahnya untuk mencapai tujuan 
Mahrani, et al/Jurnal Ekonomi Syariah Teori dan Terapan Vol. 6 No. 2 Fevbruari 2019: 254-269; PENERAPAN PRINSIP AKAD MUDHARABAH PADA INVESTASI SYARIAH HEWAN TERNAK PT IJADGRUP RAHMAT SEMESTA

sebagaimana dituangkan dalam akad tersebut dengan baik.

- Modal yang dimiliki telah habis atau tidak ada.

\section{METODE PENELITIAN}

\section{Pendekatan penelitian}

Pendekatan yang digunakan pada penelitian ini adalah pendekatan kualitatif

\section{Ruang Lingkup Penelitian}

Keseuaian akad mudharabah yang digunakan dalam praktik investasi ternak pada PT ljadgrup Rahmat Semesta menggunakan metode analisis kualitatif. Metode ini menganalisa dan menilai keseuaian akad mudharabah yang digunakan oleh PT ljadgrup Rahmat Semesta terhadap Fatwa DSN MUI No. 07/DSN-MUI/IV/2000 tentang Mudharabah karena Fatwa DSN MUI

\section{Jenis dan Sumber Data}

Jenis data yang digunakan dalam penelitian ini adalah data primer dan sekunder.Data primer adalah jenis data yang diperoleh dari sumber baik individu, atau perorangan atau dokumen.Data primer dalam penelitian ini diperoleh dari hasil wawancara kepada pendiri dan staff, dan melalui dokumentasi yang berisi tentang perkembangan dan bukti lapangan tentang produk tersebut.

Data sekunder merupakan data yang mendukung penelitian, yang didapatkan secara tidak langsung dari suatu objek yang berupa arsip, laporan, dan dokumen yang relevan.Data sekunder dalam penelitian ini diperoleh dari data mengenai skema akad mudharabah, jumlah investor dan jumlah hewan ternak.

\section{Prosedur Pengumpulan Data}

a. Persiapan Awal, Mengidentifikasi rumusan masalah serta tujuan penelitianserta mengurus surat oengantar penelitian dari Fakultas Ekonomi dan Bisnis

b. Penelitian Lapangan, melakukan pengambilan data melalui wawancara, pengumpulan dokumen serta melakukan kajian pustaka dan literatur

\section{Teknik Keabsahan Data}

Dalam peneltian ini triangulasi sumber data dilakukan dengan cara membandingkan hasil wawancara dengan isi suatu dokumen yang berkaitan guna memperoleh keterkaitan antar data, sedangkan triangulasi metode dilakukan dengan cara membandingkan hasil wawancara dari satu informan dengan informan yang lainnya.

\section{Teknik Analisis Data}

Menurut Yin (2014:140) terdapat tiga teknik yang dapat digunakan untuk menganalisis suatu studi kasus yaitu teknik penjodohan pola, analisis deret waktu dan pembuatan eksplanasi. Bentuk teknik analisis data yang dapat digunakan dalam penelitian studi kasus adalah teknik penjodohan pola. Penjodohan pola studi kasus akan relevan dengan pola variabelvariabel spesifik yang diprediksi dan ditentukan sebelum pengumpulan data. 
Mahrani, et al/Jurnal Ekonomi Syariah Teori dan Terapan Vol. 6 No. 2 Fevbruari 2019: 254-269; PENERAPAN PRINSIP AKAD MUDHARABAH PADA INVESTASI SYARIAH HEWAN TERNAK PT IJADGRUP RAHMAT SEMESTA

\section{HASIL DAN PEMBAHASAN}

\section{Hasil Identifikasi Produk Investasi Syariah}

Berdasarkan hasil penelitian dilapangan Saat ini di ljadfarm sendiri terdapat tiga hewan ternak yang dijadikan sebagai objek investasi mudharabah.Produk yang ditawarkan adalah sebagai berikut :

1. Domba

Untuk investasi domba, memiliki jangka waktu investasi 6- 8 bulan untuk mengelola dana investasinya mulai dari penggemukan hewan hingga hewan siap dipanen dan dijual. Biaya investasi untuk domba sebesar Rp 950.000 per ekor dengan return sekitar $15-20 \%$

2. Kambing

Untuk investasi kambing, memiliki jangka waktu investasi 6- 8 bulan untuk mengelola dana investasinya mulai dari penggemukan hewan hingga hewan siap dipanen dan dijual. Biaya investasi untuk domba sebesar Rp 1.250.000 per ekor dengan return sekitar $17-22 \%$

3. Sapi

Untuk investasi sapi, memiliki jangka waktu investasi 6- 8 bulan untuk mengelola dana investasinya mulai dari penggemukan hewan hingga hewan siap dipanen dan dijual. Biaya investasi untuk domba sebesar Rp 2.000.000 per orang dengan return sekitar $15-20 \%$

Investasi sendiri dalam Al-quran sendiri telah banyak disinggung dan secara jelas diajurkan untuk kaum muslimin untuk mencapai kemsashlahatan umat.

Prinsip dari ljadfarm sendiri adalah menciptakan dan memberikan manfaat tentunya tidak untuk ljadfarm saja namun bagi orang lain serta lingkungan sekitar. Manfaat lain yang dimaksut adalah seperti pemberian pupuk kompos, biogas secara gratis pada masyarakat desa yang disitu terdapat kandang dari ljadfarm. Selain itu mereka juga memperluas lapangan pekerjaan dengan membuka kemitraan dengan para peternak desa. Berdasarkan data yang diperoleh dari website ijadfarm.com ada 156 peternak yang menjadi mitra ternak dari ljadfarm , 2440 hektar lahan menjadi produktif, 36.000 meter kubik biogas dan 380 ribu ton pupuk kompos tersalurkan. Tentu manfaat tersebut dapat dirasakan sekali.

Dengan adanya prinsip tersebut maka dapat kita jumpai ayat pada Al Quran yang juga memerintahkan umat muslim untuk saling tolong-menolong serta memberikan manfaat bagi sesamanya.Seperti yang tertera pada surat An-Nisa 114.

\section{Hasil Penerapan Prinsip Syariah pada Produk Investasi ljadfarm}

Mekanisme pelaksanaan produk investasi syariah ljadfarm( PT ljadgrup Rahmat Semesta) Surabaya menggunakan akad mudharabah atau lebih dikenal sebagai akad bagi hasil. Dan berikut analisis kesesuaian akad mudharabah di ljadfarm dengan aturan Fatwa DSN-MUI mengenai pembiayaan mudharabah. 
Mahrani, et al/Jurnal Ekonomi Syariah Teori dan Terapan Vol. 6 No. 2 Fevbruari 2019: 254-269; PENERAPAN PRINSIP AKAD MUDHARABAH PADA INVESTASI SYARIAH HEWAN TERNAK PT IJADGRUP RAHMAT SEMESTA

Shahibul maalakan diberi form kesepakatan untuk diisi sebelum terjadi akad antara pihak ljadfarm dengan calon shahibul maal. Setelah form diisi, maka terjadi akad dan kesepakatan antara kedua belah pihak termasuk nisbah bagi hasil serta ketetapan-ketetapan yang harus dilaksanakan oleh ljadfarm maupun shahibul maal. Setelah dana tersampaikan ke ljadfarm, maka ljadfarm selaku mudharib, mengfusikan dana tersebut untuk membeli hewan ternak, merawat hingga menjualnya ketika panen. Hal ini sesuai dengan ketentuan fatwa DSN-MUI bahwa pembiayaan yang disalurkan oleh LKS melalui akad mudharabah iniharus pada usaha yang produktif bukan disalurkan untuk keperluan konsumtif.

Akad perjanjian mudharabah ini tidak hanya diungkapkan dengan lisan antara mudharib dan shahibul maal akan tetapi juga tertulis dalam form akad perjanjian mudharabah yang memuat juga pasal-pasal di dalamnya. Hal ini sesuai dengan aturan fatwa yang tertulis bahwa akad dituangkan secara tertulis, melalui korespondensi, atau dengan menggunakan cara-cara komunikasi modern. Selain itu, ljadfarm juga menyediakan dua pilihan untuk calon shahibul maal dalam melakukan akad persetujuan yaitu dengan cara langsung datang ke kantor atau secara online dengan mengisi terms \& agreement yang terdapat pada website ljadfarm.

Dalam pembiayaan mudharabah ini, nisbah yang dibagi hasilkan kepada kedua belah pihak adalah hasil keuntungan dari usaha yang dijalankan oleh mudharib setelah dikurangkan dengan biaya-biaya yang dikeluarkan untuk usaha tersebut.Sesuai dengan fatwa DSN MUI bahwasanya keuntungan mudharabah adalah jumlah yang didapat sebagai kelebihan dari modal.

Fatwa juga mengatur mengenai kegiatan usaha mudharib bahwasanya kegiatan usaha adalah hak eksklusif mudharib, tanpa campur tangan penyedia dana, tetapi ia mempunyai hak untuk melakukan pengawasan. Hal ini sesuai dengan praktik yang dilakukan oleh ljadfarm bahwa shahibul maal tidak ikut campur dalam mengurus usaha, hanya melakukan pengawasan, pembinaan serta membantu mempromosikan saja, pengelolaan usaha diserahkan sepenuhnya kepada mudharib.

Aturan fatwa DSN-MUI tentang pembiayaan mudharabah ini adalah penyedia dana tidak boleh mempersempit tindakan pengelola sedemikian rupa yang dapat menghalangi tercapainya tujuan mudharabah, yaitu keuntungan. Demikian yang dilakukan pada sistem investasi mudharabahljadfarm bahwa kegiatan usaha sepenuhnya dikerjakan oleh mudharib dan shahibul maal men-support penuh kemajuan usaha tersebut tidak menghalangi ataupun ikut campur dalam manajemen usaha tersebut.

\section{Pembahasan}

ljadfarm selalu berpegangan terhadap prinsip syariah serta fatwa yang 
Mahrani, et al/Jurnal Ekonomi Syariah Teori dan Terapan Vol. 6 No. 2 Fevbruari 2019: 254-269; PENERAPAN PRINSIP AKAD MUDHARABAH PADA INVESTASI SYARIAH HEWAN TERNAK PT IJADGRUP RAHMAT SEMESTA

dibuat oleh dewan syariah dan juga didiskusikan dengan komisaris bidang syariahnya yang saat ini sedang menempuh pendidikan di Universitas Islam Madinah mulai dari perencanaan pengadaan produk baru sampai dengan aplikasi kesehariannya.Hal tersebut sesuai dengan fatwa yang tertulis yaitu pengelola tidak boleh menyalahi hukum Syari'ah Islam dalam tindakannya yang berhubungan dengan mudharabah, dan harus mematuhi kebiasaan yang berlaku dalam aktifitas itu.

Dalam pembiayaan mudharabah ini, nisbah yang dibagi hasilkan kepada kedua belah pihak adalah hasil keuntungan dari usaha yang dijalankan oleh mudharib setelah dikurangkan dengan biaya-biaya yang dikeluarkan untuk usaha tersebut.Sesuai dengan fatwa DSN MUI bahwasanya keuntungan mudharabah adalah jumlah yang didapat sebagai kelebihan dari modal.

Fatwa juga mengatur mengenai kegiatan usaha mudharib bahwasanya kegiatan usaha adalah hak eksklusif mudharib, tanpa campur tangan penyedia dana, tetapi ia mempunyai hak untuk melakukan pengawasan. Hal ini sesuai dengan praktik yang dilakukan oleh ljadfarm bahwa shahibul maal tidak ikut campur dalam mengurus usaha, hanya melakukan pengawasan, pembinaan serta membantu mempromosikan saja, pengelolaan usaha diserahkan sepenuhnya kepada mudharib.

Dalam fatwa, diatur bahwa mudharabah boleh dibatasi pada periode tertentu.Produk investasi mudharabah di ljadfarm pun demikian bahwa jangka waktu pembiayaan mudharabah ditentukan atas permintaan mudharib yang disesuaikan dengan kebutuhan usaha mudharib dan disepakati oleh shahibul maal.Seperti yang tertera di website dari ljadfarm bahwa periode investasi mudharabah selama 6-8 bulan.

Fatwa selanjutnya mengenai aturan pembiayan mudharabah adalah kontrak tidak boleh dikaitkan (mu'allaq) dengan sebuah kejadian di masa depan yang belum tentu terjadi. Hal ini juga sesuai dengan yang dilakukan oleh ljadfarm bahwa investasi mudharabah di ljadfarm ini tidak ditargetkan bagi hasil fix berupa nominal tetapi menyesuaikan dengan hasil dari usaha yang dijalankan karena perjalanan dari suatu bisnis atau usaha tersebut adalah fluktuatif sehingga mengikuti perjlanan bisnis tersebut.

Fatwa DSN MUI selanjutnya adalah pada dasarnya, pada mudharabah tidak ada ganti rugi, karena pada dasarnya akad ini bersifat amanah lyad alamanah), kecuali akibat dari kesalahan disengaja, kelalaian, atau pelanggaran kesepakatan. Menurut informan sepanjang perjalanan aplikasi akad mudharabah tidak pernah mengalami kerugian dan mengganti rugi, akan tetapi jika suatu saat ditemukan kerugian akibat kelalaian dari salah satu pihak, maka akan dibicarakan secara musyawarah terlebih dahulu untuk membicarakan ganti rugi yang harus ditanggung. Selain itu, 
Mahrani, et al/Jurnal Ekonomi Syariah Teori dan Terapan Vol. 6 No. 2 Fevbruari 2019: 254-269; PENERAPAN PRINSIP AKAD MUDHARABAH PADA INVESTASI SYARIAH HEWAN TERNAK PT IJADGRUP RAHMAT SEMESTA

ljadfarm sendiri telah menyiapkan danataawun yang merupakan dana yang diambil $10 \%$ dari investasi awal sebagai bentuk antisipasi apabila hewan ternak meninggal dunia. Namun apabila tidak terjadi apa-apa pada hewan tersebut, dana $10 \%$ tersebut akan dikembalikan.

Sebagai aturan pamungkas, pada fatwa DSN-MUI no.07/DSN-MUI/IV/2000 dituliskan bahwa jika salah satu pihak tidak menunaikan kewajibannya atau jika terjadi perselisihan di antara kedua belah pihak, maka penyelesaiannya dilakukan melalui Badan Arbitrasi Syari'ah setelah tidak tercapai kesepakatan melalui musyawarah. Hal ini sesuai dengan praktik investasi mudharabah di ljadfarm bahwa di ljadfarm jika terjadi perselisihan atau kesalahfahaman tetap mengutamakan jalur kekeluargaan yakni jalur musyawarah. Apabila jalur kekeluargaan tidak berjalan dengan baik maka terpaksa akan ditempuh jalur hukum.

\section{KESIMPULAN DAN SARAN}

\section{Simpulan}

1. Produk investasi dari ljadfarm yang berakad mudharabah yang terdiri dari investasi domba, kambing, hingga sapi ini dalam menjalankan prinsip syariahnya sesuai dengan Fatwa Fatwa Dewan Syariah Nasional Majelis Ulama Indonesia (Fatwa DSN MUI) No.07/DSN-MUI/IV/2000 tentang pembiayaan mudharabah.

2. Dalam investasi pada sektor peternakan, investasi syariah yang menggunakan akad mudharabah ini sendiri memiliki tingkat kemudahan, kepercayaan serta hasil yang lebih baik. Yang dimaksud dengan hasil yang lebih baik ialah kedua belah pihak sama-sama tidak dirugikan dalam masa pengelolaan dana investasinya.

3. Pada ljadfarm sendiri, penawaran akad yang ditawarkan ada dua yakni secara langsung maupun tidak langsung. Akad tidak langsung ini sendiri merupakan akad kesepakatan dua pihak yang dilakukan secara online. Hal tersebut merupakan salah satu inovasi yang dapat memudahkan masyarakat untuk berinvestasi dan juga dalam praktiknya, akad secara online diperbolehkan dan tetap dinyatakan sah.

\section{Saran}

1. Bagi ljad farm

a. Hendaknya dapat melakukan kajian yang lebih mendalam dan pengembangan mengenai mudharabah sendiri dalam penerapannya di peternakan dan mengkaji terus-menerus permasalahan terbaru dengan komisaris di bidang syariah yang ada di ljadfarm.

b. Mempermudah akses bagi para peneliti dalam melakukan penelitiannya.

c. Diharapkan penelitian ini dapat memberi gambaran dan pertimbangan terhadap proses penerapan investasi 
Mahrani, et al/Jurnal Ekonomi Syariah Teori dan Terapan Vol. 6 No. 2 Fevbruari 2019: 254-269; PENERAPAN PRINSIP AKAD MUDHARABAH PADA INVESTASI SYARIAH HEWAN TERNAK PT IJADGRUP RAHMAT SEMESTA

yang berlandaskan prinsip syariah dalam investasi hewan ternak dan sesuai dengan fatwa DSN MUI No. 07/DSNMUI/IV/2000 agar praktik investasi syariah yang dijalankan dapat sesuai dengan prinsip syariah.

2. Bagi penelitian selanjutnya

a. Peneliti selanjutnya yang melakukan penelitian dengan topik yang sama hendaknya dapat menambah jenis-jenis investasi syariah yang dapat dikembangkan dalam bisnis peternakan serta menambah objek-objek peternakan syariah di Indonesia

b. Selalu semangat dalam mengerjakan skripsi karena bisa jadi hasil penelitian dari skripsi anda merupakan ladang berdakwah bagi anda dan bermanfaat untuk masyarakat umum.

\section{DAFTAR PUSTAKA}

Affandi,L., Dikman, D.M dan Aryogi. 2007. Petunjuk Teknis Manajemen Perkawinan Sapi Potong. Pasuruan. Loka Penelitian Sapi Potong

Antonio, Syafii. 2001. Bank Syariah dari Teori ke Praktik. Jakarta. Gema Insani

Fatimah, Siti. 2011. Pelaksanaan Sistem Bagi Hasil Ternak Sapi di Desa Sejangat Ditinjau Menurut Konsep Mudharabah.Pekanbaru.
Universitas Islam Negeri Sultan Syarif Kasim Riau

Haming dan Basalamah. 2003. Studi Kelayakan Investasi: Proyek dan Bisnis. Jakarta. PPM

Hanoem, Halida. 2012. Kesevaian Implementasi Akad Mudharabah Musytarakah Pada Perusahaan Asuransi Takaful Keluarga Surabaya. Surabaya. Universitas Airlangga

Haroen, Nasrun. 2007. Fiqh Muamalah. Jakarta. Gaya Media Pertama

Henry Simamora. 2000. Basis Pengambilan Keputusan Bisnis. Salemba Empat. Jakarta

Iskandar, L. 2009. Geografi 2 : Kelas XI SMA dan MA. Jakarta. PT Remaja Rosdakarya

Karim Adiwarman. 2007. Bank Islam:Analisis Figh dan Keuangan. Jakarta. PT Raja Grafindo Persada

Salim dan Budi. 2008. Hukum Investasi di Indonesia. Jakarta. PT Raja Grafindo Persada

Mansur. 2009. Seluk Beluk Ekonomi Islam.Salatiga. STAIN Salatiga Press

Masadi, A.Ghufron. 2002. Fiqh Muamalah Kontekstual. Semarang. PT Raja Grafindo Persada

Muhammad. 2004. Teknik Bagi Hasil Keuntungan pada Bank Syariah. Yogyakarta. UII Press

Muhammad. 2014. Manajemen Keuangan Syariah. Yogyakarta.UPP STIM YKPN Muslich, A.Wardi. 2010. Figh Muamalat. Jakarta. Amzah 
Mahrani, et al/Jurnal Ekonomi Syariah Teori dan Terapan Vol. 6 No. 2 Fevbruari 2019: 254-269; PENERAPAN PRINSIP AKAD MUDHARABAH PADA INVESTASI SYARIAH HEWAN TERNAK PT IJADGRUP RAHMAT SEMESTA

Nafik, Muhammad. 2009. Bursa Efek dan Investasi Syariah. Jakarta. Serambi IImu Semesta

Sabiq, Sayyid. 1997. Fiqhus Sunnah jilid 3. Riyadh. Daarul Muayyad

Sugiyono. 2014. Metode Penelitian Kuantitatif, Kualitatif dan R\&D. Bandung. CV Alfabeta.

Sukirno, Sadono. 1997. Pengantar Teori Mikro Ekonomi Edisi 2. Jakarta. PT Raja Grafindo Persada

Sunariyah, 2003.Pengantar Pengetahuan Pasar Modal Edisi 3. Yogyakarta.UPP-AMP YKPN

Suwiknyo, D. 2009. Kompilasi Tafsir AyatAyat Ekonomi Islam. Yogyakarta. Pustaka Pelajar

Yin, K.Robert.2014.Studi Kasus "Desain \& Metode". Jakarta. PT Raja Grafindo Persada

Outlook Daging Sapi Kementrian Pertanian tahun 2016. 